\title{
EFFECT OF EXERCISE ON EARLY REHABILITATION OF PATIENTS WITH NEUROLOGICAL DISORDERS
}

\author{
EFEITO DO EXERCÍCIO NA REABILITAÇÃO PRECOCE DE PACIENTES COM DESORDENS NEUROLÓGICAS
}

Original Article

ARTIGO ORIGINAL

EFECTODEL EJERCICIO EN LAREHABILITACIÓN TEMPRANA DE PACIENTES CON TRASTORNOS NEUROLÓGICOS

Artículo Original

\author{
Fen Yang' (1D \\ (Physician) \\ Yihu $\operatorname{Tan}^{2}$ (DD \\ (Physician) \\ Ming Xiao ${ }^{3}$ (D) \\ (Physician)
}

1. General Hospital of The Yangtze River Shipping, Wuhan, China. 2. Hubei Provincial Hospital of Integrated Chinese \& Western Medicine, Wuhan, China.

3. General Hospital of The Yangtze River Shipping, Wuhan, China.

\section{Correspondence:}

Yihu Tan. Wuhan, 430024, China. YihuTan7@163.com

\begin{abstract}
Introduction: Acute cerebral infarction refers to the deficiency of the blood supply to the brain and the damage of tissue function. Objective: To study the effect of exercise training in early rehabilitation of patients with hemiplegia treated in the neurology department. Methods: Ninety-six patients with acute cerebral infarction hemiplegia were studied. According to the order of admission, 96 patients were divided into a control group and an early recovery group, with 48 patients in each group. Results: Before early rehabilitation, there was no statistical significance in NIHSS and FUGL-Meyer scores between the two groups $(P>0.05)$. After early rehabilitation, the NIHSS score of early rehabilitation group was lower than both its pre-early-rehab score and the control group score, while the FUGL-Meyer score was higher than both its pre-early-rehab and the control group score $(P<0.05)$. Before early rehabilitation, there was no significant difference in the GQOLI-74 score between the two groups $(P>0.05)$. After early rehabilitation, the GQOLI-74 score was higher in the early rehabilitation group than both its pre-early-rehab score and the control group score $(P<0.05)$. Conclusions: The clinical effect of early rehabilitation training in acute cerebral infarction patients with hemiplegia is significant and can further improve the clinical treatment of patients and their quality of life. Level of evidence Il; Therapeutic studies - investigation of treatment results.
\end{abstract}

Keywords: Sports; Hemiplegia; Rehabilitations.

\section{RESUMO}

Introdução: O infarto cerebral agudo refere-se à deficiência do fornecimento de sangue para o cérebro e ao dano da função tecidual. Objetivo: Estudar o efeito do treinamento físico na reabilitação precoce de pacientes com hemiplegia tratados no departamento de neurologia. Métodos: Foram estudados 96 pacientes com hemiplegia por infarto cerebral agudo. De acordo com a ordem de admissão, 96 pacientes foram divididos em grupo controle e grupo recuperação precoce, com 48 pacientes em cada grupo. Resultados: Antes da reabilitação precoce, não havia significância estatística nos escores NIHSS e FUGL-Meyer entre os dois grupos $(P>0,05)$. Depois da reabilitação precoce, o escore NIHSS do grupo reabilitação precocefoi menor do que o escore antes da reabilitação precocee o escore do grupo controle, enquanto o escore FUGL-Meyer foi maior do que antes da reabilitação precocee do grupo controle $(P<0,05)$. Antes da reabilitação precoce, não houve diferenç̧ a significativa no escore GQOLI-74 entre os dois grupos $(P>0,05)$. Depois da reabilitação precoce, o escore GQOLI-74 foi maior no grupo reabilitação precoce do que antes da reabilitação precoce e no grupo controle $(P<0,05)$. Conclusões: O efeito clínico do treinamento de reabilitação precoce em pacientes com infarto cerebral agudo com hemiplegia é significativo e pode melhorar ainda mais o tratamento clínico dos pacientes esua qualidade devida. Nível de Evidência ll; Estudos terapêuticos-Investigação dos resultados do tratamento.

Descritores: Esportes; Hemiplegia; Reabilitação.

\section{RESUMEN}

Introducción: El infarto cerebral agudo se refiere a la deficiencia del suministro de sangre al cerebro y al daño de la función del tejido. Objetivo: Estudiar el efecto del entrenamiento físico en la rehabilitación temprana de pacientes con hemiplejia tratados en el departamento de neurología. Métodos: Se estudiaron noventa y seis pacientes con hemiplejia por infarto cerebral agudo. Según el orden de ingreso, se dividieron 96 pacientes en grupo de control y grupo de recuperación temprana, con 48 pacientes en cada grupo. Resultados: Antes de la rehabilitación temprana, no hubo significancia estadística en las puntuaciones de NIHSS y FUGL-Meyer entre los dos grupos $(P>0,05)$. Después de la rehabilitación temprana, la puntuación NIHSS del grupo de rehabilitación temprana fue menor que la puntuación antes de la rehabilitación tempranay la puntuación del grupo de control, mientras que la puntuación FUGL-Meyer fue mayor que antes de la rehabilitación temprana y el grupo de control $(P<0,05)$. Antes de la rehabilitación temprana, no hubo diferencias significativas en la puntuación GQOLI-74 entre los dos grupos $(P>0,05)$. Después de la rehabilitación temprana, la puntuación GQOLI-74 fue mayor en el grupo de rehabilitación temprana que antes de la rehabilitación temprana yen el grupo de control $(P<0,05)$. Conclusiones: El efecto clínico del entrenamiento de rehabilitación temprana en pacientes con infarto cerebral agudo con hemiplejia es significativo y puede mejorar aún más el tratamiento clínico y la calidad de vida de los pacientes. Nivel de Evidencia ll; Estudios terapéuticos - Investigación de los resultados del tratamiento.

Descriptores: Deportes; Hemiplejía; Rehabilitación. 


\section{INTRODUCTION}

Acute cerebral infarction disease refers to the tissue function damage caused by insufficient brain blood supply, and its pathogenesis is closely related to basic cerebral vascular lesions, thrombosis, sclerosis and other factors, people with frequent occurrence of this disease include basic cardiovascular and cerebrovascular diseases, such as hypertension, coronary heart disease and diabetes, and the incidence is closely related to bad living habits of patients, such as smoking and alcoholism. ${ }^{1}$ This kind of disease is a common critical and severe clinical disease with a long onset, rapid progression and a high possibility of deterioration, and most patients may be accompanied by varying degrees of disability, hemiplegia is common, affecting patients' daily self-care and activity ability, leading to movement disorders, and causing severe psychological anxiety. ${ }^{2}$ Faulkner $J$ et al., in response to this research question, suggested that after cerebral infarction, the central nervous system function of the body is not completely lost, and the recovery rate is high, and behavioral intervention can promote the recovery of patients. ${ }^{3}$ Giannaki C D et al believed that strengthening physical function training, daily behavior training, health education and psychological comfort, strengthening discharge guidance, with the cooperation of family members, the patient can be assisted with rehabilitation exercise and regularly returned to the hospital for review, which can ensure the rehabilitation effect. ${ }^{4}$

\section{METHOD}

\section{General Information}

The subjects were 96 patients with acute cerebral infarction hemiplegia admitted to a hospital from May 2016 to October 2017. According to the order of admission, 96 patients were divided into control group and early recovery group, 48 patients in each group. In the control group, there were 25 males and 23 females. The age ranged from 53 to 74 years, with an average of $(62.41 \pm 4.98)$ years. In the early rehabilitation group, there were 26 males and 22 females. Age ranged from 50 to 75 years, with an average of (62.05 \pm 4.95$)$ years. There was no significant difference in general data between the two groups $(P>0.05)$.

\section{METHODS}

Routine treatment and nursing were performed in both groups. The control group began rehabilitation training after the stabilization of the disease (usually 3 to 5 days after the operation), first of all, they were trained to turn over and sit up on the sickbed, while their family members or nursing staff assisted with passive limb movement, 10-15 min/time, 2-3 times $/ d$, and then transition to get out of bed, standing, walking, step by step, training intensity can be tolerated by patients is appropriate. ${ }^{5}$ The early rehabilitation group increased the early rehabilitation training, the specific content is as follows.

1. Body placement was implemented on the first day of hospitalization. Pillows were placed under the shoulders, hips and knees of patients in supine and side decubitus positions, to keep the knee and hip of the affected side flexed, and the upper shoulder blade of the affected limb extended the elbow and wrist forward. ${ }^{6}$

2. turn over training, since the first day of hospitalization, turn over every $2 \mathrm{~h}$ during the day, try not to completely help patients turn over, but to help guide patients turn over, patients are encouraged to take the initiative to turn over by Bobath handshake, those who cannot turn over independently will be assisted step by step to guide patients to master skills and gradually be able to take the initiative to turn over.?

3.Muscle strength training when the patient's vital signs maintain smoothly for more than 48 hours, the muscle strength training was started. According to the muscle strength classification of the patient's limbs, active and passive muscle strength exercise plans were made for the patient, the sequence of joint activities was roughly small and progressive, from $30 \mathrm{~min}$ to $1 \mathrm{~h}$ each time, once a day.

Sitting balance training, the patient can independently maintain sitting for at least 30 minutes to start the training, using the sitting balance training method, the patient sitting at the bedside, the healthy side hands hold the guardrail, with the help of the nursing staff to keep the balance of the sitting position, then switch to good hand holding guardrail to maintain sitting balance, good hand supporting bed surface assist, remove good hand to maintain sitting balance alone, complete a group of training. Then the equilibrium state was broken and a new set of training movements were performed, 3-5 times per day, 2-3 times per day according to the patient's condition. ${ }^{8}$

\section{Statistical Methods}

SPSS19.0 statistical software was used to analyze the data, and the counting data was represented by $n / \%$ and tested by $x^{2}$, the measurement data were represented by $\bar{x} \pm s$ and $t$ test, and $\mathrm{P}<0.05$ was considered statistically significant.

\section{RESULTS}

Comparison of peripheral blood EPCs and SDF-1 levels between the two groups before and after nursing

Before nursing, there was no significant difference in the levels of EPCS and SDF-1 in peripheral blood between the two groups ( $P>0.05$ ). After nursing, the levels of EPCs and SDF-1 in peripheral blood of early rehabilitation group were higher than those of control group and before nursing $(P<0.05)$, as shown in Table 1.

\section{Comparison of neurological impairment degree and motor function between the two groups before and after nursing}

Before nursing, there was no statistical significance in NIHSS and FUGL-Meyer scores between the two groups $(P>0.05)$. After nursing, $\mathrm{NIHSS}$ score of early rehabilitation group was lower than that of pre-nursing and control group, while Fugl-Meyer score was higher than that of pre-nursing and control group $(\mathrm{P}<0.05)$. (Table 2$)$

\section{Comparison of quality of life between the two groups before and after nursing}

Before nursing, there was no significant difference in GQOLI-74 score between the two groups ( $P>0.05)$. After nursing, the score of Gqoll-74 in the early rehabilitation group was higher than that in the control group and before nursing $(P<0.05)$. (Table 3 )

Table 1. Comparison of peripheral blood EPCs and SDF-1 levels between the two groups before and after nursing.

\begin{tabular}{c|c|c|c|c}
\hline \multirow{2}{*}{ Group } & \multicolumn{2}{|c|}{ EPCs } & \multicolumn{2}{c}{ SDF-1 ${ }^{\alpha}$} \\
\cline { 2 - 5 } & Care before & $\begin{array}{c}\text { After the } \\
\text { nursing }\end{array}$ & Care before & $\begin{array}{c}\text { After the } \\
\text { nursing }\end{array}$ \\
\hline Early recovery group & 0.57 & 1.51 & 1211.73 & 1.794 \\
\hline The control group & 0.54 & 0.81 & 1208.99 & 1.402 .5 \\
\hline $\mathrm{t}$ & 0.407 & 9.225 & 0.118 & 13.085 \\
\hline $\mathrm{p}$ & 0.684 & 0 & 0.905 & 0 \\
\hline
\end{tabular}

Table 2. Comparison of neurological impairment degree and motor function between the two groups before and after nursing.

\begin{tabular}{c|c|c|c|c}
\hline \multirow{2}{*}{ Group } & \multicolumn{2}{|c|}{ NIHHSS score } & \multicolumn{2}{c}{ Fugl-Meyer score } \\
\cline { 2 - 5 } & Care before & $\begin{array}{c}\text { After the } \\
\text { nursing }\end{array}$ & Care before & $\begin{array}{c}\text { After the } \\
\text { nursing }\end{array}$ \\
\hline Early recovery group & 25.91 & 11.04 & 56.16 & 85.70 \\
\hline The control group & 25.94 & 16.72 & 56.88 & 80.27 \\
\hline $\mathrm{t}$ & 0.034 & 8.789 & 0.353 & 6.882 \\
\hline $\mathrm{p}$ & 0.973 & 0 & 0.723 & 0 \\
\hline
\end{tabular}




\section{Satisfaction degree of patients in the two groups after nursing}

The satisfaction degree of the early rehabilitation group was higher than that of the control group. (Figure 1)

Table 3. Comparison of quality of life between the two groups before and after nursing

\begin{tabular}{c|c|c}
\hline Group & Care before & After the nursing \\
\hline Early recovery group & 39.83 & 64.18 \\
\hline The control group & 40.16 & 58.53 \\
\hline $\mathrm{t}$ & 0.295 & 6.858 \\
\hline $\mathrm{p}$ & 0.771 & 0 \\
\hline
\end{tabular}

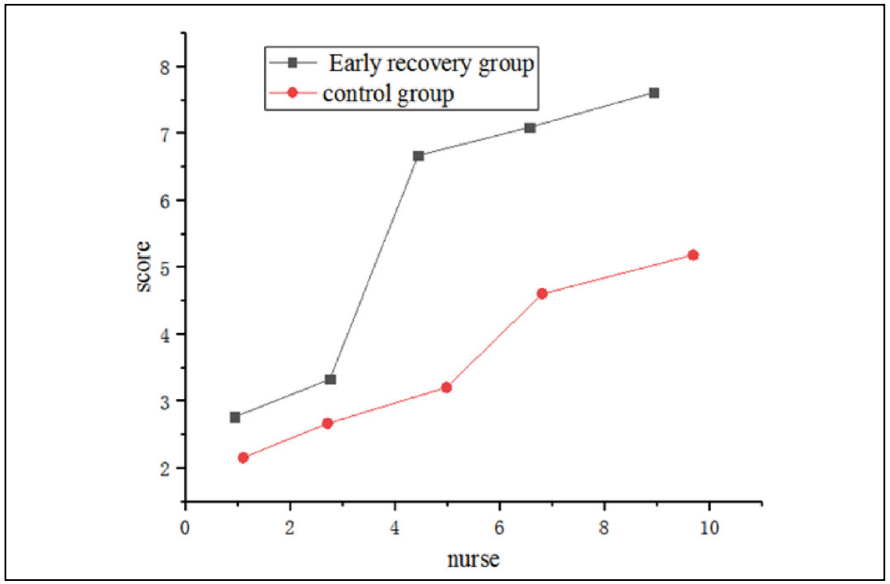

Figure 1. Satisfaction degree of patients in the two groups after nursing.

\section{DISCUSSION}

Since entering the new century, rehabilitation medicine has developed rapidly, and the rehabilitation nursing of patients with acute cerebral infarction hemiplegia has been widely concerned, a large number of studies have found that rehabilitation nursing can promote the neurological recovery of patients with acute cerebral infarction hemiplegia, reduce the degree of disability of patients, and even restore the limb function of patients to the pre-disease state. ${ }^{9}$ Based on the above research status, combined with the long-term treatment and nursing experience of patients with acute cerebral infarction hemiplegia, this study formulated the early rehabilitation exercise training program for patients, and explore the effect of this program on the treatment effect of patients, the results show that, before nursing, there was no statistical significance in the levels of EPCs and SDF-1 in peripheral blood between the two groups $(P>0.05)$. Early practice studies have confirmed the related mechanisms of early rehabilitation training to promote brain nerve recovery, including early exercise training can promote the reconstruction of posterior brain nucleus function; EPCs are important precursor cells of angiogenesis in adult individuals. ${ }^{10}$ Under normal physiological conditions, these cells mainly exist in bone marrow, the level of peripheral blood is low, and it has certain proliferation and differentiation ability, when the body tissue suffers ischemia and hypoxia, EPCs will transfer from bone marrow to peripheral blood under the action of a variety of cytokines, participate in repair of vascular endothelial injury and improve tissue blood supply. SDF-1, a member of the CXC chemokine family, is secreted by many organs and is rarely expressed in the nervous system. After cerebral ischemia or hypoxia, astrocytes in ischemic penumbra region are activated and secreted, and transferred to peripheral blood to promote repair of vascular injury. According to the expression changes of EPCs and SDF-1 in patients, early rehabilitation training can promote the repair of tissue injury. Analysis of the overall nursing effect of the two groups of patients shows that early rehabilitation training can promote the repair of patients'neurological function and tissue damage, therefore, the rehabilitation effect of patients in the early rehabilitation group is better than that of the control group.

\section{CONCLUSION}

The application effect of early exercise rehabilitation training in the clinical nursing of patients with acute cerebral infarction hemiplegia was significant, it can further improve the clinical treatment effect and improve the quality of life of patients. With the onset of hemiplegia, patients with severe psychological disorders, manifested as depression, fear, worry, despair and other feelings, so psychological care for patients is also very necessary, the follow-up will continue to in-depth research.

All authors declare no potential conflict of interest related to this article

AUTHORS' CONTRIBUTIONS: Each author made significant individual contributions to this manuscript. Fen Yang: writing and performing surgeries; Yihu Tan: data analysis and performing surgeries, Ming Xiao: article review and intellectual concept of the article.

\section{REFERENCES}

1. Young AJ, Song JE, Ann HW, Jeon Y, Ahn MY, Jung IY, et al. Effects of Early Exercise Rehabilitation on Functional Recovery in Patients with Severe Sepsis. Yonsei Med J. 2018;59(7):843.

2. Pearson MJ, Smart NA. Effect of exercise training on endothelial function in heart failure patients: A systematic review meta-analysis. Int J Cardiol. 2017;231:234-43.

3. Faulkner J, Mcgonigal G, Woolley B, Stoner L, Wong L, Lambrick D. A randomized controlled trial to assess the psychosocial effects of early exercise engagement in patients diagnosed with transient ischaemic attack and mild, non-disabling stroke. Clin Rehabil. 2015;29(8):783-94.

4. Giannaki CD, Sakkas GK, Karatzaferi C, Maridaki MD, Koutedakis Y, Hadjigeorgiou GM, et al. Combination of Exercise Training and Dopamine Agonists in Patients with RLS on Dialysis: A Randomized, Double-Blind Placebo-Controlled Study. ASAIO J. 2015;61(6):738-41.

5. Armstrong HF, Bartels MN, Paslavski O, Cain D, Shoval HA, Baloon JS, et al. The impact of aerobic exercise training on cardiopulmonary functioning in individuals with schizophrenia. Schizophr Res. 2016;173(1-2):116-7
6. Yang L, Jie Z, Deng Y, Zhang P. The Effects of Early Exercise on Motor, Sense, and Memory Recovery in Rats With Stroke. Am J Phys Med Rehabil. 2016;96(3):1.

7. Ostman C, Jewiss D, Smart NA. The Effect of Exercise Training Intensity on Quality of Life in Heart Failure Patients: A Systematic Review and Meta-Analysis. Cardiology. 2016;136(2):79-89.

8. Dziubek W, Kowalska J, Kusztal M, Rogowski L, Gołębiowski T, Nikifur M, et al. The Level of Anxiety and Depression in Dialysis Patients Undertaking Regular Physical Exercise Training - a Preliminary Study. Kidney Blood Press Res. 2016;41(1):86-98.

9. Arakawa I, Koide K, Takahashi M, Mizuhashi F. Effect of the tongue rotation exercise training on the ora functions in normal adults - Part 1 investigation of tongue pressure and labial closure strength. J Oral Rehabi. 2015;42(6):407-13.

10. Mcginley SK, Armstrong MJ, NG Boulé, Sigal RJ. Effects of exercise training using resistance bands on glycaemic control and strength in type 2 diabetes mellitus: a meta-analysis of randomised controlled trials. Acta Diabetol. 2015;52(2):221-30. 